\title{
No longer burning down the house
}

Written by: Lyndon Thompson, OECD Observer writer-at-large

Last update: 3 March 2020

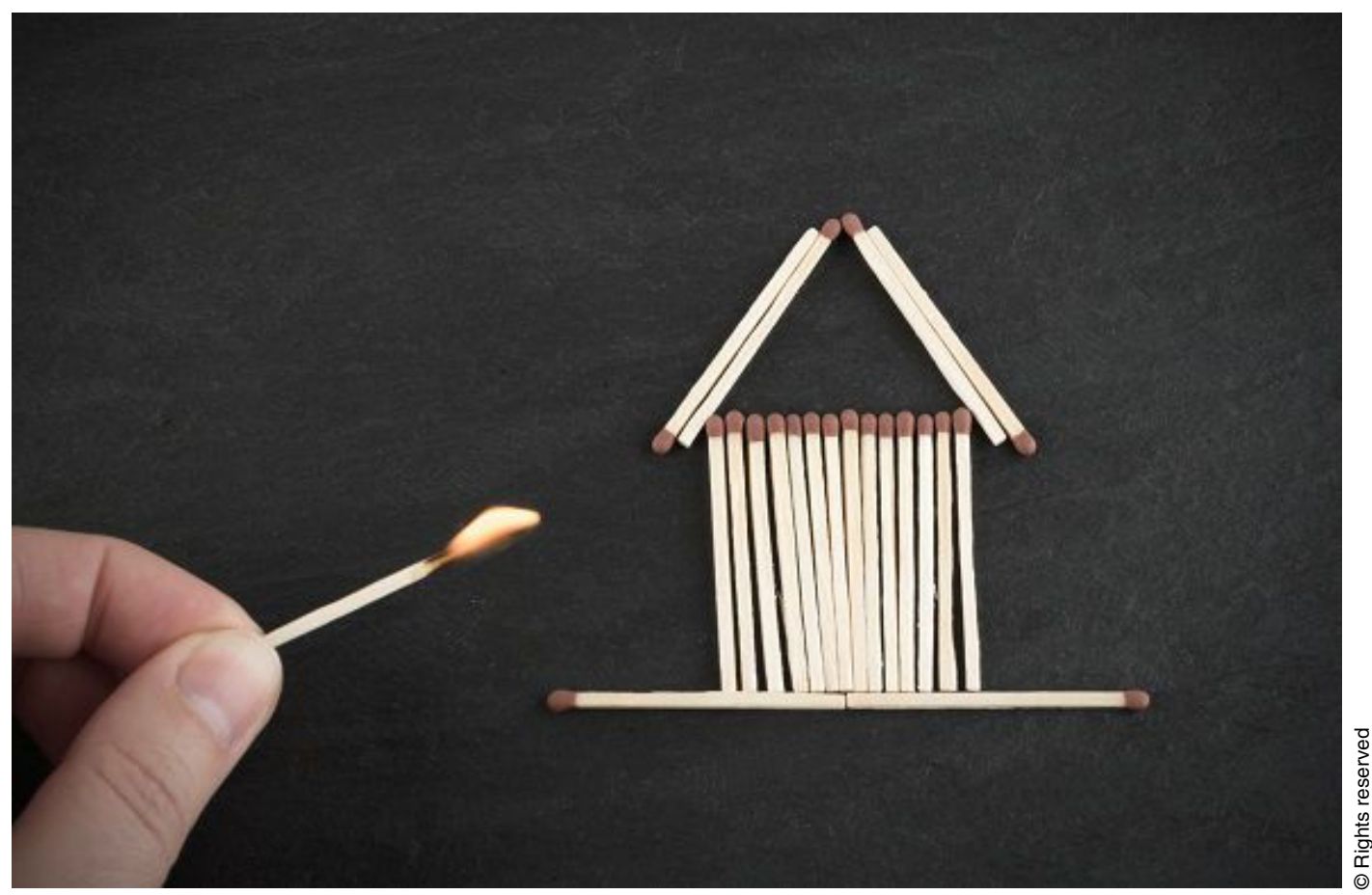

No longer burning down the house image I Image for No longer burning down the house article

In the early 1600s in North America, colonists ruined by a bad crop would often move on to new territory. In order to save on costs, they would burn down their homes to collect the nails, which would be used to build their next house. The image is one of restlessness and ingenuity, and mobility, contributing to a myth that many people there still cherish.

Tyler Cowen, a US economist invited to speak the OECD Forum in May 2018, has exploded that myth. Americans, he warned, are sunk into a dangerous complacency, and although "opportunity is not dead", Americans are not rising to the occasion." The spirit of enterprise, the historical wellspring of American character, is drying up. The number of US citizens under 30 who set up a business has fallen $65 \%$ percent since the 1980 s. Over the last 20 years, international patents from the US have fallen $25 \%$. Complacency is not necessarily bad, said $\mathrm{Mr}$ 
Cowen, if you're in Denmark, but if you have a national debt in the trillions, it's unwise to lay down tools.

Mr Cowen's findings support those of the American political economist, Nicholas Eberstadt, who in an essay last year, cited some disquieting figures. While paid work hours in the US rose by 35\% between 1985 and 2000, they crept up a meagre $4 \%$ from 2000 to 2015, and for every unemployed man between the ages of 25 and 55 seeking work in the US, three others have given up entirely. Even people who have a job, albeit an unsatisfactory one, are less willing to pull up stakes and look elsewhere. The rate at which people in the US changed jobs has dropped a quarter since 1990.

Once, moving to a new city or state brought with it the hope of raising oneself and one's family out of poverty. But now, Mr Cowen said, "poverty, rather than being a reason to move, has become a reason not to move."

Many, it seems, are resigning themselves to poverty, or at best to a negligible upward mobility. The situation is not unique to the United States. In June, the OECD published a report highlighting the decline of social mobility-it takes generations for low-income earners to move up a notch. Figures show that the bottom $40 \%$ of the population in OECD countries hold only $3 \%$ of the total wealth, and the top $10 \%$ about half. Over a four-year period, $60 \%$ of people in the bottom $20 \%$ of income distribution were still stuck there. But how the mighty have not fallen: $70 \%$ of those at the top of the ladder stay there as well. Social mobility was greater in the US than, for example, in France, Germany or the UK, yet even in the US among the poorest $10 \%$ of earners, it would take five generations for someone to secure a decent living; in Denmark it would be two.

And there is that tenuous bridge-the middle class-which has held the richest and poorest together. It has collapsed in parts. Today, middle class earners in the bottom $40 \%$ of earnings face a greater risk of slipping into poverty than they were 20 years ago.

Opportunity is turning into a tough game of draughts, with black pieces restricted to black squares and red pieces to red squares-with only the very occasional jump. The present malaise has instilled a fierce distrust of political institutions, traditional news media and globalisation. People-not just the poor, but small business owners, students, working mothers-feel their needs are being ignored or simply do not see themselves in the promise of a world economy. Populist outsiders are chosen over career politicians, traditional news media are rejected in favour of politically biased "news" websites.

There is even more physical pain, especially among the unemployed. A survey published in 2017 by the Brookings Institution, a US think tank, found that nearly half of prime age unemployed men in the United States took pain medication on a daily basis, two thirds of which were on prescription. Some $40 \%$ of unemployed 
workers also said that pain prevented them from accepting jobs for which they were qualified.

Why are so many of the unemployed in pain? When asked whether this malaise was responsible for the current political climate, Tyler Cowen said it was too early to tell, but that it probably had played a part.

The increasing political and economic polarisation in OECD countries is clearly a threat to democracy and trust, and runs contrary to the spirit of co-operation in which the organisation was founded, and which has helped improve billions of people's lives. Going back in time is not an option. To discourage colonial farmers from burning down their houses for the nails, the English Crown promised to provide the equivalent number of nails to the former tenants, leaving the houses standing for the next tenants. For social mobility to succeed, policies must restore both opportunities and confidence. Burning down the house is not an option either.

\section{References}

Cowen, Tyler (2017), “The Unseen Threat to America: We Don't Leave Our Hometowns", Real Clear Politics, 27 February, www.realclearpolitics.com/ 2017/02/27/the_unseen_threat_to_america_we_don039t_leave_ our_hometowns 403689.html

Eberstadt, Nicholas (2017), “Our Miserable 21st Century”, Commentary, 15 February, www.commentarymagazine.com/articles/our-miserable-21stcentury/

Krueger, Alan B. (2017), "Where Have All the Workers Gone? An Inquiry into the Decline of the U.S. Labor Force Participation Force", Brookings Papers on Economic Activity, September 7-8, www.brookings.edu/wp-content/uploads/ 2017/09/1_krueger.pdf

OECD (2018), A Broken Social Elevator? How to Promote Social Mobility, OECD Publishing, https://doi.org/10.1787/9789264301085-en http://dx.doi.org/ https://doi.org/10.1787/9789264301085-en

Visit www.oecd.org/oecdeconomicoutlook www.oecd.org/ oecdeconomicoutlook 